\title{
The Role of Financial Technology Toward Financial Inclusion in Indonesia: Chance and Challenge
}

\author{
Lino Harsih Khaerunnisa \\ School of Business and Management Institut Teknologi Bandung
}

\begin{abstract}
The trend of financial technology has been increase significantly for the last two years. It can be measured by the number of total transaction which reached USD 15.022 billion and the players in the Industry which grow up to 78 percent. The number of mobile banking user in Indonesia also increases higher than other Asian Country and even global average. Based on Indonesia Gross Domestic Product (GDP), financial service becomes the highest sector growth. However, the benefits of all this development have not spread evenly among Indonesian society. This is reflected on Gini coefficient that has risen over the past decade. Indonesia is still within the catchup phase of economic development. Improving financial inclusiveness may assist this regard. Access to financial sector believed could lead people to better opportunity and help them out of poverty. To enhance financial inclusion, more attention could be given to less costly methods of services provision such as mobile phone banking or mobile money. This is absolutely brings chance and challenge for financial technology industry. It includes product characteristic, regulation, industry competitiveness and customers.
\end{abstract}

Keywords: Financial Technology, Financial Inclusion, Internet of Thing

\section{Introduction}

The trend of financial technology has been increase significantly for the last two years. According to Indonesia FinTech Association (2016), total transaction of FinTech reached USD 15.022 billion a year. The role of internet boost the spread of innovation widely include updates on technology. People can get access on information easily. Then, the impact on the economy is real. Based on MEF survey, there are 80 percent mobile banking user in Indonesia. Just two years before that, the number is only 58 percent. It's higher than other Asian country and even global average. As mobile-first country, most of mobile-based innovation are easy to adopt by the society. Even though there are some 
constrains (Daily Social, 2015). Furthermore, monthly report on Social Economy shows that Indonesian Gross Domestic Product (GDP) grow 5.02 percent by 2016. The growth spread on all sectors, but the highest is in financial service with percentage of 8.90 (BPS, 2017).

Life cycle of innovation is also getting shortened and shortened. People might need 68 years to adapt with aero plane technology. Then adapt with cable telephone, television, and internet in 50 years, 14 years, and 7 years respectively, but only 3 years for iPod and 2 years for Facebook. Besides that, 50 years ago, the card payment used embossed card, magnetic stripe, and then contact chip. But less than ten years ago, we started using contactless chip and now NFC (Near-field communication) mobile (BI FinTech Office, 2017). Human become more and more developed. They always look for innovation to make their life easier. As homo-economicus, further reflected on the economic behavior, people will tend to avoid cost and maximize return.

However, amid the rapid growth of information and technology, the benefits have not spread evenly among Indonesian society. This is reflected on Gini coefficient that has risen over the past decade. Annual per capita income is around USD 9,300 in purchasing power parity terms. Indonesia is still within the catch-up phase of economic development. It needs to accelerate the deepening and broadening of its financial system by encouraging formal domestic savings and facilitating the mobilization of funds from nonbank institution to finance investment (OECD Surveys, 2015). Improving financial inclusiveness may assist this regard. To enhance financial inclusion, more attention could be given to less costly methods of services provision such as mobile phone banking. This has been a success in countries like Kenya and Philippines (World Bank, 2012).

In 2011, the World Bank launched the Global Findex in over 140 countries to study how adults save, borrow, make payments, and manage risk. This update of the Findex tracks progress on global financial inclusion over time, including the gender gap. Sri Mulyani Indrawati, World Bank Managing Director and Chief Operating Officer said, "When a woman has an account and a safe place to save outside the home, she also has greater control over finances and household incomes" (World Bank. 2015). Many studies show that access to financial services can help people out of poverty.

\section{Financial Inclusion}

There is no standard definition of financial inclusion, but several institutions give the definition as below.

"State in which all working age adults have effective access to credit, savings, payments, and insurance from formal service providers. Effective access involves convenient and responsible service delivery, at a cost affordable to the customer and sustainable for the 
provider, with the result that financially excluded customers use formal financial services rather than existing informal options" (CGAP-GPFI).

"financial inclusion involves providing access to an adequate range of safe, convenient and affordable financial services to disadvantaged and other vulnerable groups, including low income, rural and undocumented persons, who have been underserved or excluded from the formal financial sector" (FATF).

It can be conclude that financial inclusion is a condition in which people have an access to financial services, especially for the low income and unreachable group of people in formal financial sector.

Access to financial sector is believed that could lead people to better opportunity and help them out of poverty. The financial services - not just loans, but savings, insurance, payments, pensions, and other products, when coupled with related nonfinancial services, such as consumer awareness, training, and market information, can lead to breakthrough opportunities for people who had limited economic avenues (International Finance Corporation, 2012).

\subsection{Global Financial Inclusion}

According to 2014 Global Findex, from 2011 and 2014, 700 million people became account holders at banks, other financial institutions, or mobile money service providers, and the number of "unbanked" individuals dropped 20 percent to 2 billion adults. At that period, the percentage of adults with an account increased from 51 percent to 62 percent, a trend driven by a 13 percentage point rise in account ownership in developing countries and the role of technology. In particular, mobile money accounts in Sub-Saharan Africa are helping to rapidly expand and scale up access to financial services (World Bank, 2015). Along with these findings, data also show big opportunities for increase financial inclusion among women and poor people.

Financial inclusion, measured by the Global Findex as having an account that allows adults to store money and make and receive electronic payments, is critical to ending global poverty. Studies show that broader access to, and participation in, the financial system can boost job creation, increase investments in education, and directly help poor people manage risk and absorb financial shocks. Still from the same report, there is still more work to be done to expand financial inclusion among women and the poorest households. More than half of adults in the poorest 40 percent of households in developing countries were still without accounts in 2014. And the gender gap in account ownership is not significantly narrowing: In 2011, 47 percent of women and 54 percent of men had an account; in 2014, 58 percent of women had an account, compared to 65 
percent of men. Regionally, the gender gap is largest in South Asia, where 37 percent of women have an account compared to 55 percent of men, an 18 percentage point gap (World Bank, 2015).

There is another interesting insight from the Global Findex 2014 by the World Bank. "South Asia has added 185 million adults with new accounts since 2011, but there are clear opportunities to boost usage of accounts. $46 \%$ of adults now own an account, up from $32 \%$ three years ago. In India, $43 \%$ of adults with an account made no deposits or withdrawals in the past year, and 230 million with an account pay utilities or school fees in cash. $18 \%$ of adults in South Asia own a debit card, compared to $31 \%$ in developing countries on average. Shifting payments for agricultural products from cash to accounts could help reduce the number of unbanked adults by up to 105 million or about 17\%"

Figure 2.1 Financial Development Indicators for selected ASEAN Countries in 2011

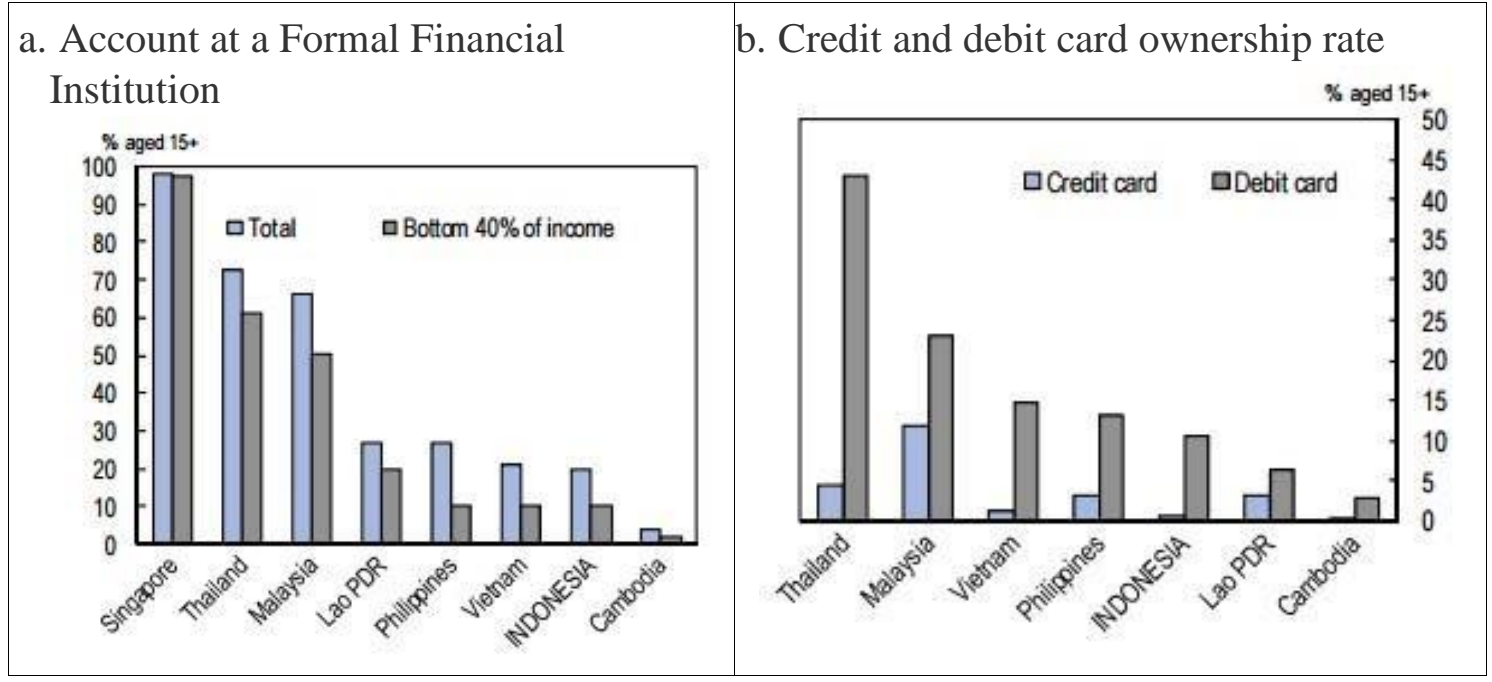


c. Electronic \& Mobile Phone Payment Made in the Last 12 Months

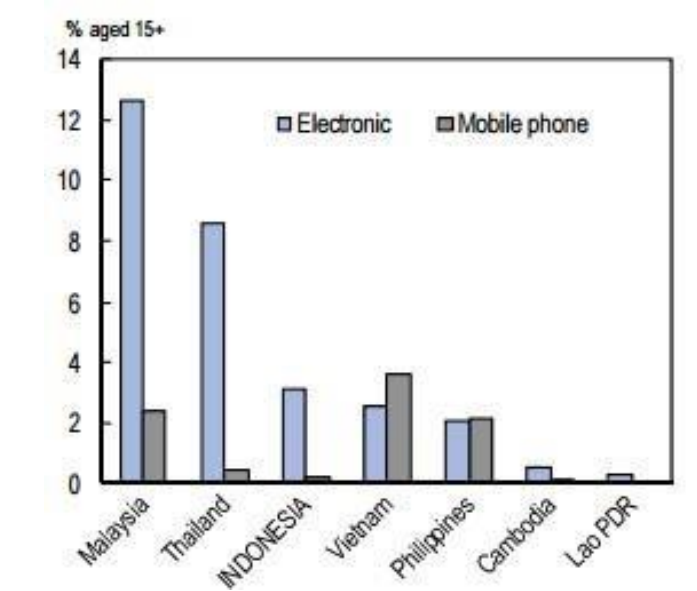

d. Borrowed from or saved with a Financial Institution in the Last 12 Month

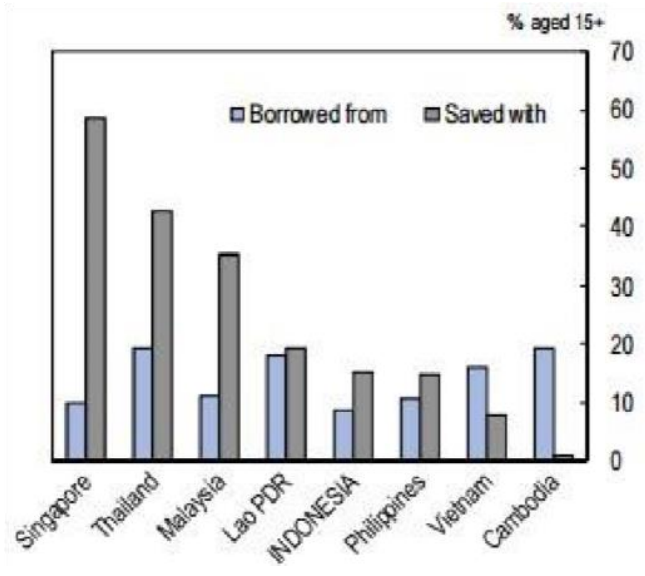

Source: OECD, 2015

\subsection{Indonesia Financial Inclusion}

The latest population census shows that Indonesia has 169 million population above 15 years old (BPS, 2010). Data from Global Findex stated that from those group of people, only 36 percent are bank account holders (Global Findex, 2014). It is equivalent to 61 million people, or one-quarter from total population. In the other word, only one of four people in Indonesia has account in financial institution. Furthermore, the report from Indonesia FinTech Association said 49 million SMEs (Small and Medium Enterprise) are unbanked. While this sector contributed to 60 percent of Indonesian GDP and employed more than 107 million workforce (AFTECH, 2017a). It is still a long way to go toward financial inclusion.

Figures 2.2 SME Contribution and Growth 


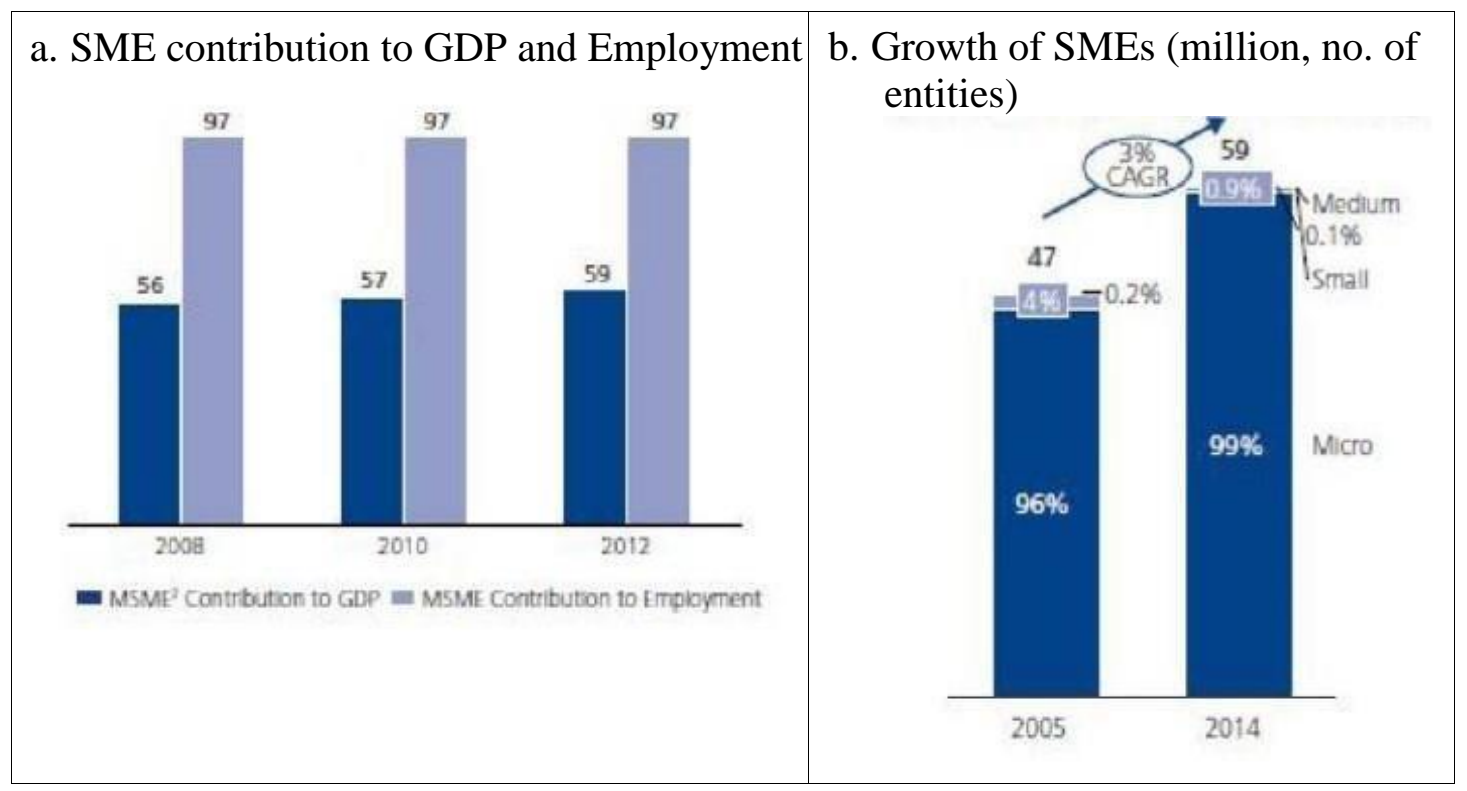

Source: AFTECH, 2017b

The central bank of Indonesia (BI, 2017) explained various reasons caused the community to be unbanked, both from the supply side and demand side. It is includes the price barrier (expensive), information barrier (less informed), product barrier design and channel barrier (appropriate product and channel). The government believed that financial inclusion can solved the problems. There are some benefits of financial inclusion for the community, government as well as private sectors as follows.

1. Improve economic efficiency

2. Support the stability of the financial system

3. Reduce shadow banking or irresponsible finance

4. Support deepening financial markets

5. Providing new potential market for banking

6. Support the improvement of Human Development Index (HDI) of Indonesia.

7. Positively contribute to sustainable local and national economic growth.

8. Reduce the inequality and low income trap rigidity in order to improve prosperity

From all over the world, there are two approaches to improve financial inclusion (or reduce financial exclusion): comprehensive and separated program. Indonesia, Nigeria, and Tanzania are samples of countries doing comprehensive approach by formulating national strategy. On the other hand, separated program was doing by the US government after the 2008 crisis by giving financial education. Generally, national strategy includes three aspect: (1) Provide appropriate services facilities; (2) Provide appropriate product and (3) provide responsible finance through financial literation and consumer protection 
(BI, 2017). It will require cooperation from all related parties. To support this program, Indonesia FinTech Association in March 2017 establish working group which responsible to build discussion with all stakeholders and create initiates to improve financial inclusion through technology especially FinTech services.

(AFTECH, 2017a)

\section{Financial Technology}

Dorfleitner et al (2017) in the book FinTech in Germany defined FinTech as rule, new participants in the market offer internet-based and application-oriented products. It generally aim to attract customers with product and services that are more user-friendly, efficient, transparent, and automated than those currently available. There is no clear definition about FinTech, but Bank Indonesia defines it as:

"A phenomenon of fusion between technology and financial features that transform business models and a weak barrier to entry which lead to raises unregulated players to run the service as well as regulated financial institution" (AFTECH, 2016)

According to Arner (2016) the term "financial technology" origin can be traced to the early 1990s with the "Financial Services Technology Consortium", a project initiated by Citigroup to facilitate technological cooperation. FinTech is often seen as the new marriage of financial services and information technology. The interlinkage is explained further in the table below.

Table 3.1. Three main periods of FinTech

\begin{tabular}{|l|l|l|l|l|}
\hline Date & $1866-1967$ & $1967-2008$ & \multicolumn{2}{|c|}{ 2008- Current } \\
\hline Era & FinTech 1.0 & FinTech 2.0 & FinTech 3.0 & FinTech 3.5 \\
\hline Geography & $\begin{array}{l}\text { Global/Develop } \\
\text { ed }\end{array}$ & $\begin{array}{l}\text { Global/Devel } \\
\text { oped }\end{array}$ & Developed & $\begin{array}{l}\text { Emerging/Dev } \\
\text { eloping }\end{array}$ \\
\hline $\begin{array}{l}\text { Key } \\
\text { elements }\end{array}$ & $\begin{array}{l}\text { Infrastructure/ } \\
\text { Computerization }\end{array}$ & $\begin{array}{l}\text { Traditional / } \\
\text { Internet }\end{array}$ & Mobile / Start-ups / New entrants \\
\hline $\begin{array}{l}\text { Shift } \\
\text { Origin }\end{array}$ & Linkages & Digitalization & $\begin{array}{l}\text { 2008 financial } \\
\text { Crisis/Smartphone }\end{array}$ & $\begin{array}{l}\text { Last mover } \\
\text { advantage }\end{array}$ \\
\hline
\end{tabular}

Source: Arner, 2016 


\section{Segment of Financial Technology}

Companies in the FinTech industry can be divided into several major segments in accordance with their distinctive business models. Financial Stability Board (FSB) divides FinTech into four areas based on its innovation types:

1. Deposits, Lending, Capital Raising

2. Payments, Clearing \& Settlement

3. Market Provisioning

4. Investment and Risk Management

Another classification introduced by Dorfleitner et al (2017) which distinguished FinTech on the basis of their involvement in financing, asset management, payments, and others. Figure 3.02 illustrate this categorization and provides a detailed representation of the sub segments of the industry.

Figure 3.2. Segment of Financial Technology

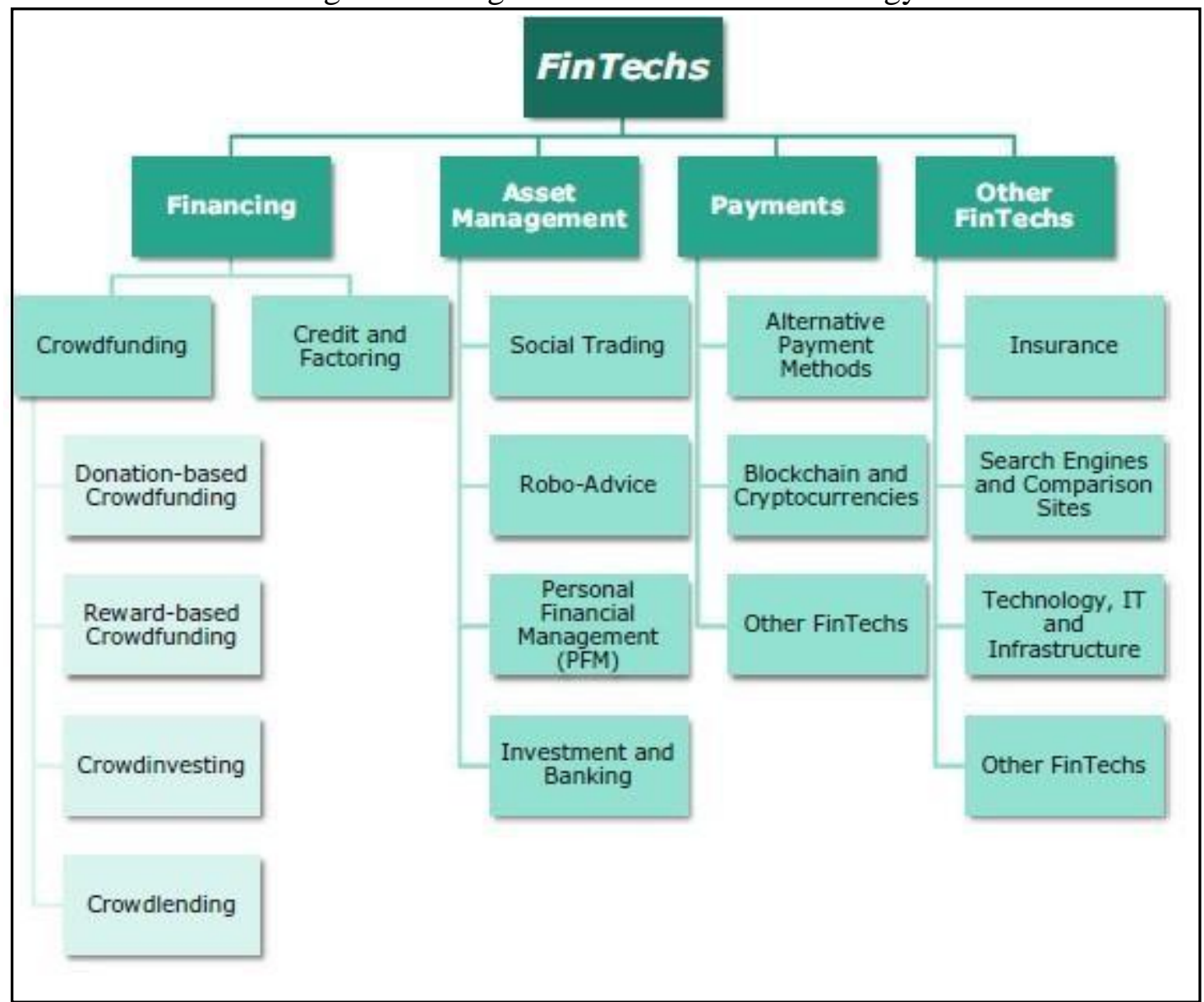

Source: Dorfleitner et al (2017) 


\subsection{Financial Technology Development in Indonesia}

Indonesia FinTech today are growing to FinTech 3.5 as Arner's Approach. Many independent tech companies (start-up) joining the financial market. With the fast pace development of Indonesia's tech ecosystem, FinTech sector also feel the impact and 2015-2016 was the best year for FinTech industry's growth.

Total transaction of FinTech reached USD 15.022 billion. 0.8 percent Personal Finance USD 8 Million; 0.3 percent Business Finance USD 5 Million. The growth of FinTech players detected for the past two years reach 78 percent, the highest number so far. By November 2016, Indonesia FinTech Association has listed around 135-140 FinTech players. The figures below show the detail.

Figure 3.3. Total Transaction and Number of FinTech Players

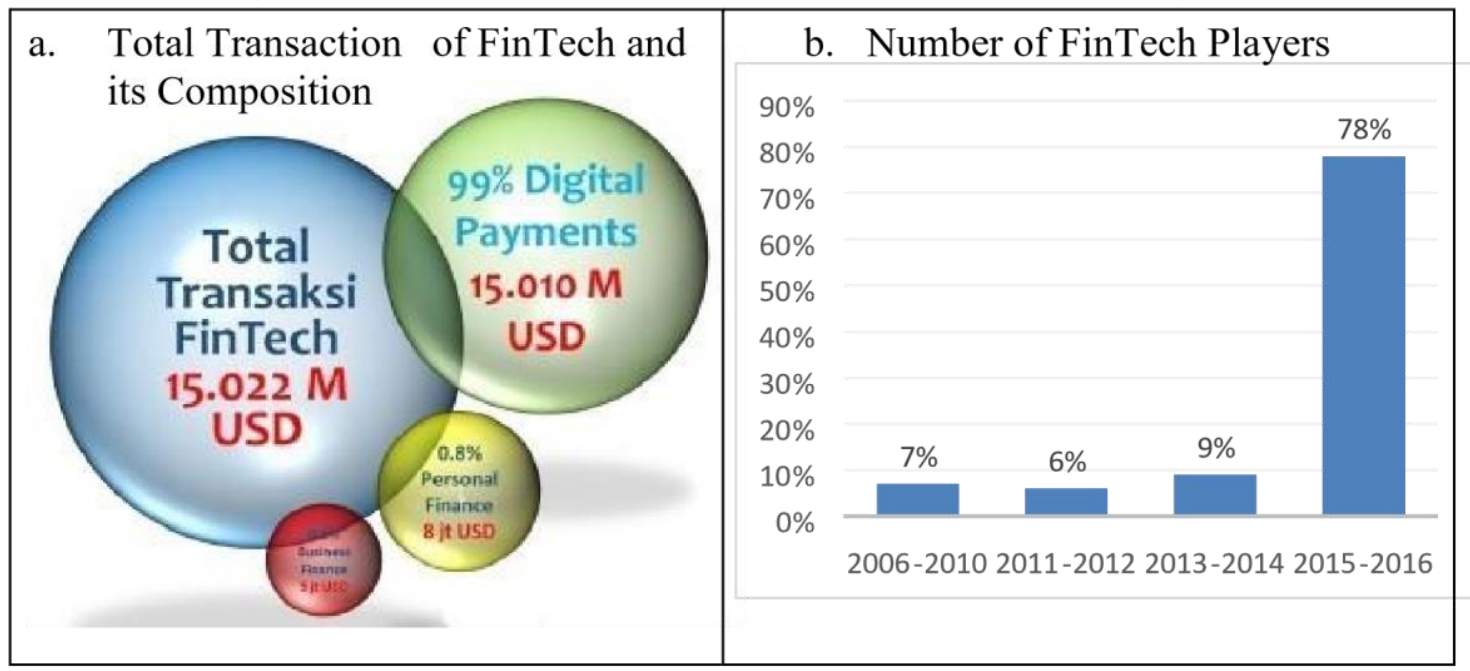

Source: Indonesia FinTech Association, 2016

The growth enables more players to emerge in Indonesia financial sector. Several years ago, the number of books, movies, and telecommunication have been disrupted by technological innovation. Now it's turn for financial services to be disrupted.

Development trend of FinTech business models is tends to replicate those incumbents of the existing institution. Based on Indonesia FinTech Association data, 43\% of FinTech players in Indonesia are playing in payment sector, from mobile payment to payment gateway company. E-commerce growth plays major part for this condition.

Figure 3.4. FinTech Player Profile by Sector 


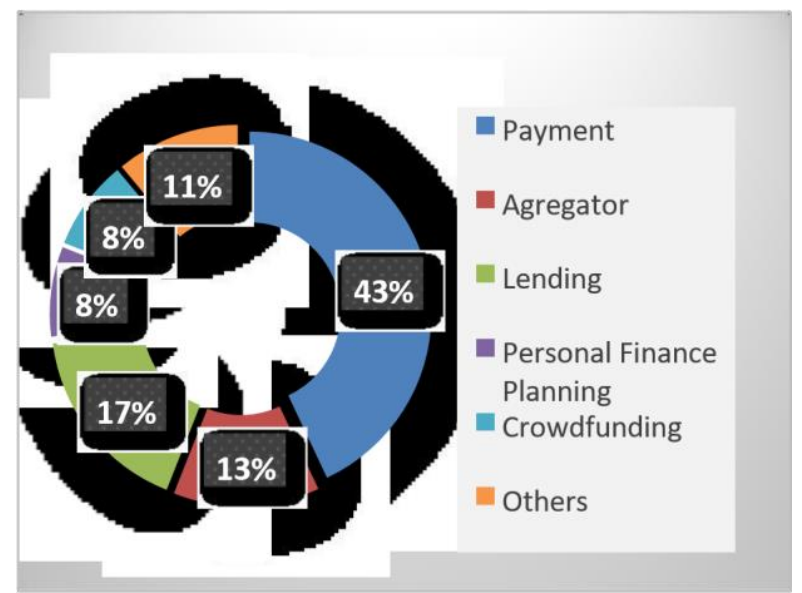

Source: Indonesia FinTech Association, 2016

\section{Benefit of FinTech}

According to BI FinTech Office (2017), there are some benefits of FinTech for customers, Players and the economy, as follows.

Benefit to customers:

1. More choices of product

2. Better quality of services

3. Lower prices

Benefit to Players:

1. Shortening transaction chain

2. Capital efficiency and operational resilience

3. Supporting Financial inclusion

4. Smoothening information flow Benefit to the economy:

1. Supporting monetary policy transmission

2. Increasing money velocity

3. Supporting Economic growth

\subsection{The Reason why FinTech flourish in Indonesia}

Combining the data from Indonesia FinTech Association (2016) and BI FinTech Office (2017), we can distinguish two main factors that support FinTech flourish in Indonesia: Push Factors and Pull Factors. 


\section{Push Factors (Generic)}

1. Internet of things (IoT). Broadband internet is become more widely available, the cost of connecting is decreasing, more devices are being created and smartphone penetration is sky rocketing. All of these things creates perfect opportunities for innovation.

2. Virtual Currencies. European central Bank defined virtual currency as a type of unregulated, digital money, which is issued and usually controlled by its developers and used and accepted among the members of a specific virtual community.

3. Advance Robotics and 3D printing. Advance innovation on technology enables the collaboration with financial sector.

4. Sharing Economy. It refers to economic ecosystem built around the sharing of assets, collaborative consumption to gain access to the products and services needed.

5. Increased access to government data. Such access can help the society for better forecast and decision maker.

6. Reinforced protection of personal data.

\section{Pull Factors (Specific)}

1. 64 percent unbanked people. 49 million SMEs unit not yet bankable. Only 36 percent adults in Indonesia have an account at the formal financial institution.

2. The penetration of bank branches only 11 bank branches over 100,000 adults (compare to European Union 62.5). It's equivalent to $1 / 6$ of the penetration in European Countries.

3. IDR 7,525 billion Gap Credit to GDP

4. Peer to peer (P2P) lending is still under IDR.150 billion. The share of new credit to GDP is still 34.77 percent (Bank). It's reflects a huge market potential that can be targeted by FinTech (especially P2P lending), without having to erode banks' market share.

5. Demography: 42 percent Gen $Y$ and Gen Z

6. More than 310 million mobile phone user

7. The number of Internet user has exceeded over 100 million (APJII: 132.7 million). And 24 million internet users are in 25-29 age range. 
8. 80 percent mobile banking user.

According to MEF survey in 2015, 80 percent respondents said that they used mobile banking. It's higher than global average and other Asian country. This number increase from 2013 with only 58 percent user. They used mobile banking to check the balance and transfer money to other party. (Daily Social, 2015).

Figure 3.5. Mobile Banking User between Selected Countries

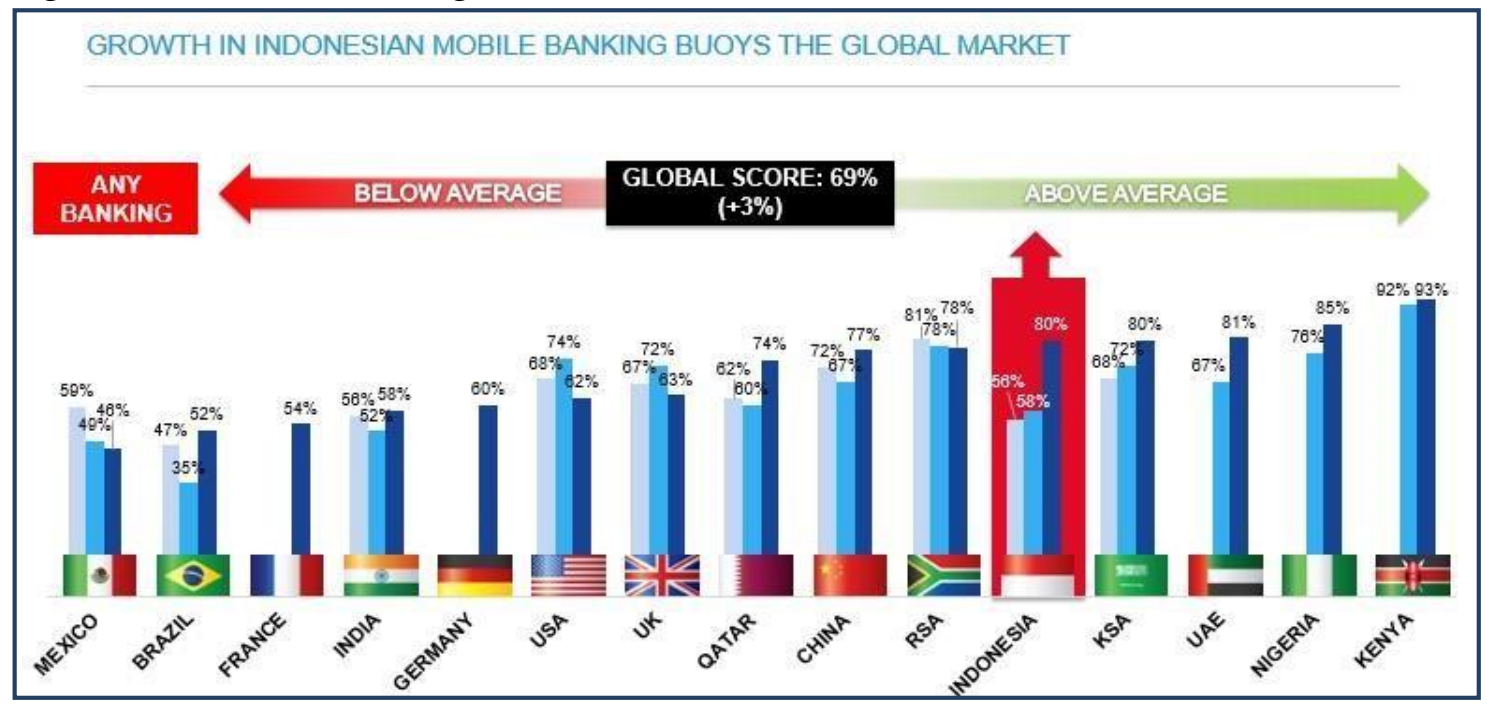

Source: MEF, 2015

\subsection{Chances \& Challenges}

Based on the data and fact explained before, we can classify the chance of financial technology as follows.

1. Product Characteristic.

FinTech industries have unique product characteristic that differentiate them with other financial services product. Those characteristics are (1) Cheap; (2) Fast; (3) Anytime (24/7); (4) Anywhere; and (5) Any device.

2. Regulation. In Indonesia, the authorities responded well. The policy response about the financial technology not to burden the business, but rather to ensure both innovation and security. BI FinTech Office with its Regulatory Sandbox had commitment to support development of FinTech in Indonesia. 
3. Industry Competitiveness. There still huge market for FinTech Industry. Based on other macroeconomics data explained before. For example in P2P lending. The share of new credit to GDP is still 34.77 percent (Bank). It's reflects a huge market potential that can be targeted by FinTech, without having to erode banks' market share.

4. Customer. Indonesia is the largest economy in Southeast Asia. The country has charted an impressive economic growth since overcoming the Asian Financial crisis in the late 1990s. The number of mobile and internet user play the main role for financial technology.

Then we can classify the challenge of financial technology as follows.

1. Product Characteristic Because of the unique characteristic of FinTech product, some future challenges arise. As mentioned before, the technology lifecycle become more shortened and shortened, the FinTech players should (1) Move fast and (2) Grow fast. The ever-changing trends and environment would lead to stagnancy if we failed to response fastly. Another product risk is might be cyber risk. Since the data storage somewhere in the cloud or server, company should protect them.

2. Regulation. Although the regulation give a chance to grow, the industry players should aware about the new regulation. Because if the business failed to adapt, it will likely become disadvantageous for the company. There are several regulations that might challenges the industry to implement such as Regulation about Financial transaction, BI Regulation on PTP (Payment Transaction Processing). Besides that, based on survey by Deloitte Consulting and Indonesia

FinTech Association (2016), almost half of FinTech players (49\%) feel that current regulatory process is slow and 61 percent of them feel that regulation in Indonesia is not so clear or in grey area.

3. Industry Competitiveness. The sector need most is payment gateway. Based on Indonesia FinTech Association data, 43\% of FinTech players in Indonesia are playing in payment sector, from mobile payment to payment gateway company. E-commerce growth plays major part for this condition.

4. Customer. According to the survey involved 1000 respondents $(51.05 \%$ female; $48.95 \%$ male) lived in Java, conducted by ATECH and Daily Social, shows that 
consumer awareness to FinTech is still low although most of them live in urban area. Yet most of them believe that FinTech can help to push on better financial literacy and financial Inclusion in Indonesia. Another challenges is trust issue. This is might be the biggest challenges for financial transaction. 32 percent mobile user said that it was the main problem, so did e-commerce and mobile wallet (Daily Social, 2015). This classic trust issue should be solved together by electronic and online based service provider.

\section{References}

Asosiasi FinTech Indonesia (AFTECH), 2017a. FinTech untuk Inklusi Keuangan Indonesia. Retrieved from https://fintech.id/ideas/ideas-detail?id=307

Asosiasi FinTech Indonesia (AFTECH), 2017b. Peer2Peer Lending - Addressing the Financing Gap. Sosialisasi Peraturan Otoritas Jasa Keuangan (POJK). Jakarta 14 February 2017

Bank Indonesia, 2017. Keuangan Inklusif: Apa, Mengapa, Bagaimana, \& Siapa.

Retrieved from http://www.bi.go.id/id/perbankan/keuanganinklusif/Indonesia/ Contents/Default.aspx

Bank Indonesia FinTech Office, 2017. FinTech Development in Indonesia: A Regulator's Perspective. Guest Lecture on FinTech Development in Indonesia at SBM ITB, Bandung 4 February 2017.

Biro Pusat Statistik (BPS), 2010. Sensus Penduduk 2010, Berdasarkan Kelompok Usia. Retrieved from http://sp2010.bps.go.id/index.php/site/ tabel?tid=336\&wid=0

Biro Pusat Statistik (BPS), 2017. Laporan Bulanan Data Sosial Ekonomi Edisi 83, April 2017. Katalog 9199017. Retrieved from. https://www.bps.go.id/website/pdf_publikasi/Laporan-Bulanan-Data-SosialEkonomi-April-2017.pdf

Consultative Group to Assist the Poor (CGAP) - G-20 Global Partnership for Financial Inclusion (GPFI), 2017. Global Standard-Setting Bodies and Financial

Inclusion for the Poor. Retrieved from http://www.gpfi.org/sites/default/files/documents/CGAP.pdf

Daily Social, 2015. MEF: Penggunaan Mobile Banking Capai 80\% di Indonesia, Isu Kepercayaan Menjadi Masalah Terbesar. Retrieved from https://dailysocial.id/post/mobile-banking-indonesia

Dorfleitner et al, 2017. FinTech in Germany. ISBN: 978-3-319-54665-0. Retrieved fromwww.springer.com/cda/content/document/cda.../9783319546650c2.pdf?SG WID

Douglas W. Arner, 2016. FinTech: Evolution and Regulation. Asian Institute of International Financial Law. University of Hong Kong. Retrieved from. 
http://law.unimelb.edu.au/_data/assets/pdf_file/0011/1978256/DArnerFinTechEvolution-Melbourne-June-2016.pdf

Finnacial Action Task Force (FATF), 2017. Anti-money laundering and terrorist financing (AML CFT) measures and Financial Inclusion. Retrieved from http://www.fatfgafi.org/media/fatf/content/images/AML\%20CFT\%20measures\% 20and\%20fina ncial\%20inclusion.pdf

Global Findex, 2014. Global Findex (Global Financial Inclusion Database). Retrieved fromhttp://databank.worldbank.org/data/reports.aspx?Id=525cbb65\&Report_Na me=AFI-NOV-2016\#

Indonesia FinTech Association, 2016. Indonesia FinTech Report 2016. Retrieved from https://dailysocial.id/report/post/indonesias-fintech-report-2016

International Finance Corporation, 2012. Stories of Impact, Financial Inclusion Creating Opportunity through Finnacial Services in South Asia. Retrieved from https://www.ifc.org/wps/wcm/connect/56af65004383c29fa956b9869243d457/Fi nancial+Inclusion.pdf?MOD=AJPERES

OECD Surveys, 2015. Ikhtisar Survey Ekonomi OECD Indonesia Maret 2015. Retrieved from https://www.oecd.org/economy/Overview-Indonesia- 2015Bahasa.pdf

World Bank, 2012. India Economic Update. September. Washington D.C

World Bank. 2015. Jumlah Penduduk Tanpa Rekening Bank Menurun Besar: Laporan Terbaru Bank Dunia. Retrieved from http://www.worldbank.org/in/news/press release/2015/04/15/massive-drop-in-number-of-unbanked-says-new-report 